Academic City University College - Accra Ghana

Society for Multidisciplinary \& Advanced Research Techniques (SMART) Africa

Tony Blair Institute for Global Change

FAIR Forward - Artificial Intelligence for All - Deutsche Gesellschaft für Internationale Zusammenarbeit (GIZ) GmbH

Accra Bespoke Multidisciplinary Innovations Conference (ABMIC)

\title{
Engineering Management Model Towards Enhancing Institutional Based Workshop Facilities
}

${ }^{1}$ Bunakiye R. Japheth, ${ }^{2}$ Evans F. Osaisai, ${ }^{3}$ Erho A. Joseph \& 4 Juliana I. Consul

1,3Department of Computer Science,

2,4Department of Mathematics,

Niger Delta University

Wilberforce Island

Bayelsa State, Nigeria.

Emails:

bunakiye.japheth@ndu.edu.ng

ef.osaisai@ndu.edu.ng

joseph.erho@mail.ndu.edu.ng

ji.consul@ndu.edu.ng

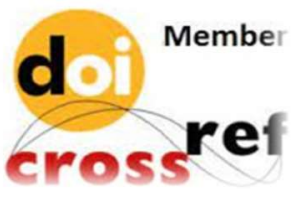

Proceedings Citation Format

Bunakiye R. Japheth, Evans F. Osaisai, Erho A. Joseph \& Juliana I. Consul (2021): Engineering Management Model Towards Enhancing Institutional Based Workshop Facilities. Proceedings of the Accra Bespoke Multidisciplinary Innovations Conference. University of Ghana/Academic

City University College, Accra, Ghana. December 2021. Pp 71-82 www.isteams.net/ghanabespoke2021.

DOI https://doi.org/ 10.22624/AIMS/ABMIC2021P6 


\title{
Engineering Management Model Towards Enhancing Institutional Based Workshop Facilities
}

\author{
Bunakiye R. Japheth, Evans F. Osaisai, Erho A. Joseph \& Juliana I. Consul
}

\begin{abstract}
This paper is focused on the use of technical personnel in the typical setting of a workshop in higher educational institutions in Nigeria. The essence is to fully manage tools for more creativity in technical work. The case study is focused on woodwork engineering management where vending cost analysis and implications model is presented to enhance productivity and reduction of requisition cost. So far, wood work refurbishing and repairs are being carried out with existing tools such as CNC-MDF Chain Saw Machine, and Automatic Edge Banding Machines respectively in quite a number of higher educational institutions in Nigeria. Now the trend has changed, more efficacious wood work requiring the production of durable stools and other furniture is needed. CNC works on the Cartesian coordinate system (X, Y, Z) for 3D motion control and parts of a project can be designed in the computer with a CAD/CAM program, and then cut automatically using cutters to produce a finished part. So these engineering trend has to be fully managed in such a way that the functionalities of these tools are fully harnessed to ensure full operations; particularly to produce for high-volume local content, skills acquisition and entrepreneurial development. The resultant effect will be to remove costly and repetitive manufacturing steps for office and other relevant furniture, and to create opportunities with future expansion for revenue generation.
\end{abstract}

Keywords: Technical Personnel, Nigerian Higher Educational Institutions, Wood Work Engineering, Vending Analysis, Entrepreneurial Development, Computer Numerical Control Machines.

\section{INTRODUCTION}

Many higher educational institutions in Nigeria have these workshops domiciled in the institutions works department or more particularly in the Faculty of Engineering Workshops. These institutions; by their ratings, status and classification needs to be properly positioned in terms of structure and facilities. This positioning in consonance with the trending entrepreneurial philosophy can be achieved by harnessing internal strength and opportunity with future expansion for wealth creation and revenue generation. Accordingly, the newly established and approved faculties' needs quality furniture to adequately carry out classroom and office based activities. Also the hostels needs quality furniture for the provision of effective accommodation for deserving occupants. It is pertinent to state further that with the vision and sustainability mantra of these higher educational institutions, patronizing vendors will cost several millions of naira, time and labour [18], especially in situations where there are trainable personnel to effectively manage the machines. A good number of the workshop personnel, are highly competent, experienced, dedicated with an amazing exceptional creativity and ingenuity in woodwork. 
Now with the introduction and availability of Medium Density Fiberboard (MDF) and Computer Numerical Control Machines (CNC), and expending same to the fullest the refurbishing and repairs of existing offices, lecture halls and hostel furniture can be successfully carried out by the personnel [19].

\subsection{Working Technicalities}

The MDF works by taking small wood fibers and gluing them together with resin under extreme heat and pressure, CNC works on the Cartesian coordinate system (X, Y, Z) for 3D motion control and parts of a project can be designed in the computer with a CAD/CAM program, and then cut automatically using cutters to produce a finished part (See Fig. 1).
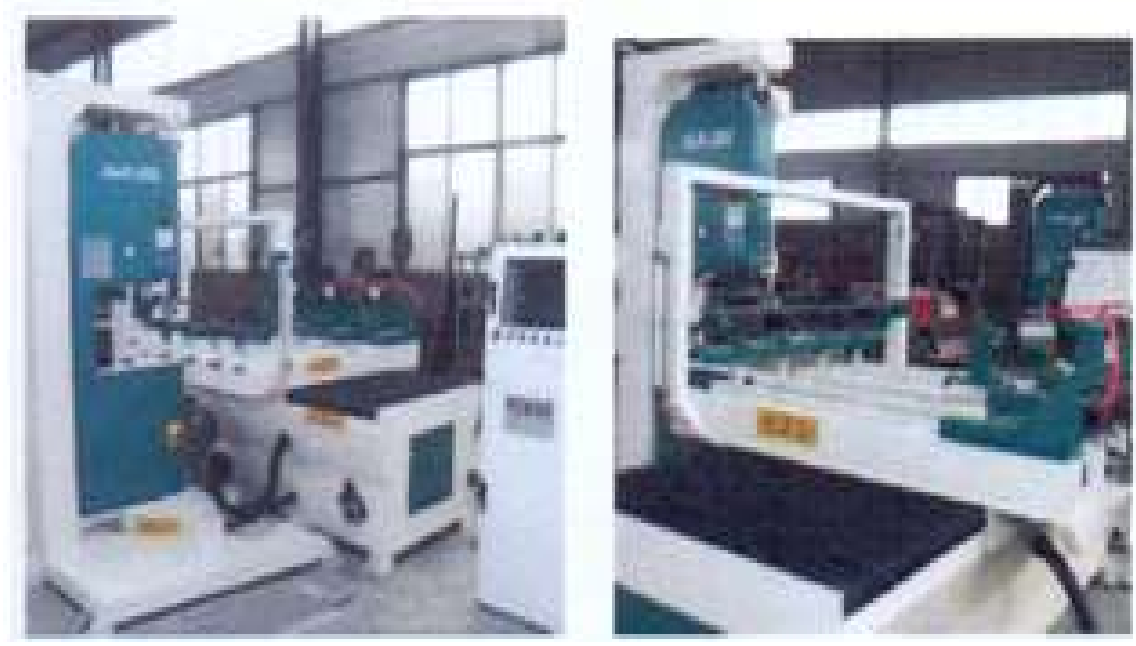

Figure 1 CNC MDF Chain Saw

The CNC, MDF Band Saw Machines create objects such as furniture from wood. More so, the Edge Banding, applies both to a process and an associated narrow strip of material used to create durable and aesthetically pleasing trim edges during finish carpentry [1]. Edge banding is used to cover the exposed sides of materials such as plywood, particle board or MDF, increasing durability and giving the appearance of a solid or more valuable material. The substitutes for edge banding include face frames or molding. Edge banding can be made of different materials including PVC or wood. Previously, traditional edge banding was a manual process requiring ordinary carpentry tools and materials.

But in recent times, modern applications, particularly for high-volume, repetitive manufacturing steps for cabinet doors, tables, beds and chairs these machines apply. Edge banding is applied to the substrate by an automated process using a hot-melt adhesive [15]. A substrate primer may also be used as a bonding agent between the adhesive and the substrate. Thicker edge bandings typically require a slight concavity to provide a tight glue line. The thickness can vary from 0.18 " to $5 \mathrm{~mm}$ or even more. The machine that applies the edge banding is called Edge bander. 


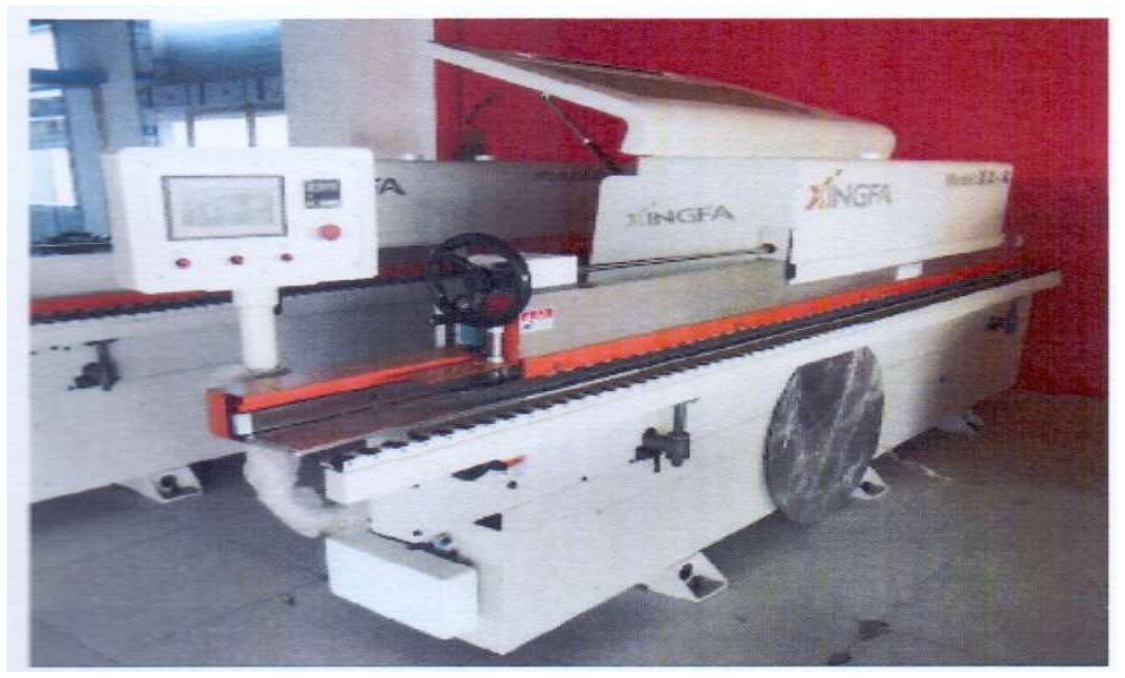

Figure 2 Automatic Edge Banding Machines

An Edge bander bonds the edge banding to the substrate, trims the leading and trailing edges, trims top and bottom flush with the substrate, scraps any surplus, and buffs the finished edge [3]. It will be germane to note, that the provision of the CNC MDF Chain Saw and Automatic Edge Banding Machines in addition to the existing Machineries in Engineering Workshop would improve the qualities, quantities, good finishing and durability enhancement of the furniture produced [8]. Global standards in terms of best practices will be met and these furniture's/products can favorably compete with those imported from Europe or America.

\section{TECHNOLOGY MANAGEMENT CAPACITY}

Office furniture is needed in all the faculties (offices and lecture halls) and the hostel [6]. So adequately equipping the workshop with the state of the art woodwork, carpentry and joinery machineries with CNC MDF Chain Saw and Automatic Edge Banding Machines can improve the production of the needed furniture. These would be economical and cost saving on the part of the institutions. It will automatically improve the qualities, quantities, good finishing and durability enhancement of the furniture produced and then put the institutions in a vantage position for skill acquisition, Internally Revenue Generation (IGR) and entrepreneurship skill development.

\section{COST ANALYSIS ESTIMATION}

This section presents the cost of purchase of furniture of an institution for the Faculties of Engineering, Basic Medical Sciences and Law. This analysis as shown in tables I to V will further provide the grounds for proper comparative cost analysis producing the same furniture using the tools available in the woodwork workshop in the university [12]. 
Table 1: Cost estimation of Desk for the Faculties of Engineering, Basic Medical Sciences and

\begin{tabular}{|c|c|c|c|c|c|c|}
\hline \multicolumn{7}{|c|}{ Law } \\
\hline $\mathrm{S} / \mathrm{N}$ & Faculty & $\begin{array}{c}\text { Number Of } \\
\text { Lecture } \\
\text { Halls }\end{array}$ & $\begin{array}{l}\text { Number Of } \\
\text { Desk Per } \\
\text { Lecture Hall }\end{array}$ & Total & $\begin{array}{c}\text { Unit Cost } \\
\quad \mathrm{N}\end{array}$ & Total Cost A \\
\hline 1. & Engineering & 10 & 220 & 2200 & $40,000.00$ & $88,000,000.00$ \\
\hline 2. & $\begin{array}{l}\text { Basic Medical } \\
\text { Science }\end{array}$ & 16 & 100 & 1600 & $40,000.00$ & $64,000,000.00$ \\
\hline 3. & Law & 9 & 120 & 1080 & $40,000.00$ & $43,200,200.00$ \\
\hline \multicolumn{4}{|r|}{ TOTAL } & 4880 & $40,000.00$ & $195,200,000.00$ \\
\hline
\end{tabular}

Table 2: Cost estimation of Purchase of Executive Office Tables for the Faculties of Engineering, Basic Medical Sciences and Law

\begin{tabular}{|l|l|c|c|c|c|l|}
\hline S/N & \multicolumn{1}{|c|}{ Faculty } & $\begin{array}{c}\text { Number Of } \\
\text { Department }\end{array}$ & $\begin{array}{c}\text { Number Of } \\
\text { Tables }\end{array}$ & Total & Unit Cost A & Total Cost A \\
\hline 1. & Engineering & 5 & 20 & 100 & $145,000.00$ & $145,000,000.00$ \\
\hline 2. & $\begin{array}{l}\text { Basic Medical } \\
\text { Science }\end{array}$ & 3 & 20 & 60 & $145,000.00$ & $8,700,000.00$ \\
\hline 3. & Law & 2 & 20 & 40 & $145,000.00$ & $5,800,000.00$ \\
\hline \multicolumn{2}{|r|}{ TOTAL } & 200 & $145,000.00$ & $29,000,000.00$ \\
\hline
\end{tabular}

Table 3: Cost estimation of Purchase of Tables in the Hostel

\begin{tabular}{|l|c|c|c|c|c|c|}
\hline S/N & Hostel & $\begin{array}{c}\text { Number Of } \\
\text { Rooms }\end{array}$ & $\begin{array}{c}\text { Number Of Person } \\
\text { Per Room }\end{array}$ & Total & $\begin{array}{c}\text { Unit Cost } \\
\text { N }\end{array}$ & Total Cost A \\
\hline 1. & Hostel & 650 & 3 & 1950 & $27,620.00$ & $53,859,000.00$ \\
\hline
\end{tabular}

Table 4: Cost estimation of Purchase of Drawing Tables for Faculty of Engineering

\begin{tabular}{|l|l|l|l|l|l|l|}
\hline S/N & Item & $\begin{array}{l}\text { Cost In } \\
\text { Dollars }\end{array}$ & $\begin{array}{l}\text { Exchange } \\
\text { Rate }\end{array}$ & Total & Unit Cost A & Total Cost A \\
\hline 1. & $\begin{array}{l}\text { Engineering } \\
\text { Drawing Tables }\end{array}$ & $\begin{array}{l}69.0 \\
\text { dollars }\end{array}$ & A350.00 & 100 & $24,150.00$ & $2,415,000.00$ \\
\hline
\end{tabular}

Table 5: Summary of Cost for the Purchase of Furniture for the Faculties of Engineering, Basic Medical Sciences and Law

\begin{tabular}{|l|l|l|l|l|}
\hline $\begin{array}{l}\text { S/ } \\
\text { N }\end{array}$ & Items & Quantity & $\begin{array}{c}\text { Cost Per Unit } \\
\text { Total Cost N }\end{array}$ & \\
\hline 1 & Total Number of Desk & 4880 & $40,000.00$ & $195,200.000$. \\
\hline 2 & $\begin{array}{l}\text { Total Number of Executive Office } \\
\text { Table }\end{array}$ & 200 & $145,000.00$ & $29,000,000.00$ \\
\hline 3 & $\begin{array}{l}\text { Total Number of Tables in Hostel } \\
\text { N350,00.00) }\end{array}$ & 1950 & $27,620.00$ & $53,859,000.00$ \\
\hline 4 & $\begin{array}{l}\text { Drawing Table (69 dollar x } \\
\text { Total Cost }\end{array}$ & $24,150.00$ & $2,415,000.00$ \\
\hline \multicolumn{3}{|c|}{ Ton } \\
\hline
\end{tabular}




\subsection{Cost of Production of Furniture}

This section presents the cost of producing the furniture for the Faculties of Engineering, Basic Medical Sciences and Law. This analysis will further help to properly comparative the production cost with the purchasing cost so that the engineering management principle applied in this circumstance with the aim of removing costly steps for acquiring office and other relevant furniture, and to create opportunities with future expansion for revenue generation can be achieved [13].

Table 6: Office Table with One Side Drawer in the Hostel

\begin{tabular}{|l|l|l|l|l|}
\hline S/N & Description & Quantity & \multicolumn{1}{|c|}{$\begin{array}{c}\text { Unit Cost } \\
(\mathbf{A})\end{array}$} & \multicolumn{1}{|c|}{$\begin{array}{c}\text { Total Cost } \\
(\mathbf{A})\end{array}$} \\
\hline 1 & $3 / 4$ mdf & 1 & $9,000.00$ & $9,000.00$ \\
\hline 2 & Edge Tape & 10 yards & 100.00 & $1,000.00$ \\
\hline 3 & Top Bond & 1 & $1,200.00$ & $1,200.00$ \\
\hline 4 & Screw Nail & 1 pw & 300.00 & 300.00 \\
\hline 5 & Drawer Roller & 3 pairs & $1,000.00$ & $3,000.00$ \\
\hline 6 & Drawer Handle & 3 & 200.00 & 600.00 \\
\hline 7 & Drawer key & 2 & 300.00 & 600.00 \\
\hline 8 & Angle Joint & 8 & 50.00 & 400.00 \\
\hline 9 & Transportation & & $1,500.00$ & $1,500.00$ \\
\hline 10 & Labour & $3,500.00$ & $3,500.00$ \\
\hline
\end{tabular}

The unit cost of producing an Office Table in the Hostel is Twenty Six Thousand, Five Hundred Naira only [17]. The total cost for 1950 Tables isN26, $500.00 \times 1950=$ N5, 167,500.00 (Five Million, One Hundred and Sixty Seven Thousand, Five Hundred Naira Only).

Table 7: Desk for Faculty of Engineering, Law and Basic Medical Science

\begin{tabular}{|c|c|c|c|c|}
\hline $\mathrm{S} / \mathrm{N}$ & Description & Quantity & $\begin{array}{l}\text { Unit Cost } \\
\text { (\#) }\end{array}$ & $\begin{array}{c}\text { Total Cost } \\
\text { (隹) }\end{array}$ \\
\hline 1 & $3 / 4 \mathrm{mdf}$ & $11 / 2$ & $9,000.00$ & $13,500.00$ \\
\hline 2 & Edge Tape 15 yards & 15 yards & 100.00 & $1,500.00$ \\
\hline 3 & Top Bond & 1 & $1,200.00$ & $1,200.00$ \\
\hline 4 & Screw Nail & $2 \mathrm{pw}$ & 300.00 & 600.00 \\
\hline 5 & Drawer Roller & 6 pairs & $1,000.00$ & $6,000.00$ \\
\hline 6 & Drawer Handle & 6 & 200.00 & $1,200.00$ \\
\hline 7 & Drawer key & 2 & 300.00 & 600.00 \\
\hline 8 & Angle Joint & 8 & 50.00 & 400.00 \\
\hline 9 & Transportation & & $1,500.00$ & $1,500.00$ \\
\hline 10 & Labour & & $3,500.00$ & $3,500.00$ \\
\hline & & & Total & $30,000.00$ \\
\hline
\end{tabular}

The unit cost of producing a Desk is Thirty Thousand Naira only Therefore, the total cost for 4880 Desk $=$ A30, $000.00 \times 4880=$ N146, 400,000.00 (One Hundred and Forty Six Million, Four Hundred Thousand Naira Only) 
Table 8: Executive Office Tables for Offices in Faculty of Engineering, Law and Basic Medical Sciences

\begin{tabular}{|c|c|c|c|c|}
\hline $\mathrm{S} / \mathrm{N}$ & Description & Quantity & $\begin{array}{l}\text { Unit Cost } \\
\text { (N) }\end{array}$ & $\begin{array}{c}\text { Total Cost } \\
\text { ( }\end{array}$ \\
\hline 1 & $3 / 4 \mathrm{mdf}$ & 3 & $9,000.00$ & $27,000.00$ \\
\hline 2 & $1 / 4 \mathrm{mdf}$ & 2 & $6,500.00$ & $13,000.00$ \\
\hline 3 & 1/2 Row of Edge Tape & $1 / 2$ Row & $4,500.00$ & $4,500.00$ \\
\hline 4 & Leather Velvet & 2 yards & $1,500.00$ & $3,000.00$ \\
\hline 5 & $1 / 2$ Board of Mouka Foam & 1 inch & $2,500.00$ & $2,500.00$ \\
\hline 6 & Top Bond & 1 & $1,200.00$ & $1,200.00$ \\
\hline 7 & 1"nail & $2 \mathrm{pw}$ & 300.00 & 600.00 \\
\hline 8 & Screw nail & $2 \mathrm{pw}$ & 300.00 & 300.00 \\
\hline 9 & Drawer Roller & 6 pairs & $1,000.00$ & $6,000.00$ \\
\hline 10 & Drawer handle & 6 & 200.00 & $1,200.00$ \\
\hline 11 & Drawer key & 2 & 300.00 & 600.00 \\
\hline 12 & Transportation & & 5000.00 & $1,500.00$ \\
\hline 13 & Labour & & $10,00.00$ & $10,000.00$ \\
\hline \multicolumn{4}{|r|}{ Total } & $66,200.00$ \\
\hline
\end{tabular}

The unit cost of producing an Executive Table is Sixty Six Thousand, Two Hundred Naira only. While the total cost of producing 200 Executive Tables isA66, 200.00 x $200=N 13,240,000.00$ (Thirteen Million, Two Hundred and Forty Thousand Naira Only).

Table 9: Engineering Drawing Tables

\begin{tabular}{|c|c|c|c|c|}
\hline $\mathrm{S} / \mathrm{N}$ & Description & Quantity & $\begin{array}{l}\text { Unit Cost } \\
\text { (A) }\end{array}$ & $\begin{array}{c}\text { Total Cost } \\
\text { (\#) }\end{array}$ \\
\hline 1 & $3 / 4 \mathrm{Hdf}$ & $1 / 2$ & $7,500.00$ & $7,500.00$ \\
\hline 2 & $1 / 2$ plywood & 1 & $3,500.00$ & $3,500.00$ \\
\hline 3 & $1 \times 12 \times 18$ Plank & 1 & $2,500.00$ & $2,500.00$ \\
\hline 4 & $2 \times 3 \times 18$ pole line & 1 & $1,200.00$ & $1,200.00$ \\
\hline 5 & Top Bond & 1 & $1,200.00$ & $1,200.00$ \\
\hline 6 & 2"nail & $1 \mathrm{pw}$ & 300.00 & 300.00 \\
\hline 7 & Leather Velvet & 2 yards & $1,500.00$ & $3,000.00$ \\
\hline 8 & $1 / 2$ Board of Mouka Foam & 1 inch & $2,500.00$ & $2,500.00$ \\
\hline 9 & 1"nail & $2 \mathrm{pw}$ & 300.00 & 600.00 \\
\hline 10 & Edge tape & 5 yards & 100.00 & 500.00 \\
\hline 11 & Sand paper & 6 yards & 150.00 & 900.00 \\
\hline 12 & Spraying material & & $2,500.00$ & $2,200.00$ \\
\hline 13 & Adjuster & & $1,500.00$ & $1,500.00$ \\
\hline 14 & Transportation & & 5000.00 & $1,500.00$ \\
\hline 15 & Labour & & $12,000.00$ & $12,000.00$ \\
\hline \multicolumn{4}{|r|}{ Total } & $38,600.00$ \\
\hline
\end{tabular}

The unit cost of producing a Drawing Table is Thirty-Eight Thousand, Six Hundred Naira only. While the total cost for 100Drawing Tables is A38, $600.00 \times 100=$ N3, 860,000.00 (Three Million, Eight Hundred and Sixty Thousand Naira Only) 


\section{VENDING COST ANALYSIS AND IMPLICATIONS FOR TECHNOLOGY MANAGEMENT}

The total cost for purchasing 4880 Desks for the Faculties of Engineering, Law and Basic Medical Science is One Hundred and Ninety-Five Million, Two Hundred Thousand Naira only $(\mathrm{A} 195,200,000.00)$ at the rate of Forty Thousand Naira (A40,000.00) per desk as shown in Table 1 [5]. From Table 2, it is seen that it will cost the University management Twenty-Nine Million Naira ( $\mathrm{N29}$, 000,000.00) to purchase Two Hundred Executive Office Table, at the rate of One Hundred and Forty-Five Thousand Naira (A145, 000.00) for the offices in the Faculty of Engineering Law and Basic Medical Sciences 16]. Table 3 shows the number of tables and cost of purchase of 1950 tables in the Hostel. it will cost Fifty Three Million, Eight Hundred and Fifty Nine Thousand Naira ( $\mathrm{A53}, 859,000.00)$ at the rate of Twenty-Seven Thousand, Six Hundred and Twenty Naira (A27, 620.00) per table, while 100 Drawing Tables in Engineering Drawing Room will cost Two Million, Four Hundred and Fifteen Thousand Naira (A2, 415,000.00) only at the rate of Twenty Four Thousand, One Hundred and Fifty Naira (A24, 150.00) as show in Table 4. Therefore, the total cost on the part of the University for the purchase of the itemized furniture would amount to Two Hundred and Eighty Million, Four Hundred and Seventy-Four Thousand Naira (A280, 474,000.00) as shown in Table 5.

\subsection{Procurement cost analysis and implications}

The CNC MDF Chain Saw Machine will cost Fifteen Million Naira ( $\$ 15,000,000.00)$ only, while the Automatic Edge Banding Machine will cost Twelve Million, Eight Hundred Thousand Naira ( $\mathrm{N} 12,800,000.00)$ only. It will cost the University a total of Twenty Seven Million, Eight Hundred Thousand Naira ( $\mathrm{A} 27,800,000.00$ ) only (excluding installation cost to purchase these good finishing machines. This is as shown in Table 10 [7].

Table X: Cost of CNC MDF Chain Saw and Automatic Edge Banding Machines

\begin{tabular}{|l|l|c|l|l|}
\hline S/N & Description & Quantity & $\begin{array}{l}\text { Unit Cost } \\
(\mathbf{N})\end{array}$ & $\begin{array}{l}\text { Total Cost } \\
(\mathbf{N})\end{array}$ \\
\hline 1 & CNC MDF Chain Saw Machine & 1 & $\mathrm{~N} 15,000,000.00$ & $\mathrm{~N} 15,000,000.00$ \\
\hline 2 & $\begin{array}{l}\text { Automatic edge Banding } \\
\text { Machine }\end{array}$ & 1 & $\mathrm{~N} 27,800,000.00$ & $\mathrm{~N} 12,800,000.00$ \\
\hline 3 & Transportation & & & \\
\hline 4 & Cost of Installation & & \\
\hline \multicolumn{2}{|c|}{ Total ( Excluding Transportation and Installation) } & $\mathrm{N} 27,800,000.00$ \\
\hline
\end{tabular}

The total cost of the materials and labour to produce the above furniture will amount to One Hundred and Sixty-Eight Million, Six Hundred and Sixty Seven Thousand, Five Hundred Naira (N168, 667,500.00) only as shown in Tables 6-9 [2]. The cost of the CNC MDF Chain Saw Machine, Automatic Edge Banding machine, material for the production of the furniture itemized above and the labour would amount to One Hundred and Ninety Six Million, Four Hundred and Sixty Seven Thousand, Five Hundred Naria (N196, 467,500.00) only. A comparative analysis of the cost implication for purchasing the furniture and producing them in the institutions Engineering Workshop shows a difference of Eighty Four Million, Six Thousand and Five Hundred Naira (A84, 006,500.00) only. This balance is in favour of producing this furniture's in the institutions Engineering Workshop. A critical examination revealed that the purchase of the CNC MDF Chain Saw and Automatic Edge Banding Machine would be highly economical, since the machine will be available for consequence production of furniture for the University in the nearest future and to create opportunities for revenue generation, and wealth creation. 
The summary of vending/procurement cost analysis and implications for the typical institution as rightly highlighted is shown in table 11 [4].

Table 11: Vending/Procurement cost analysis and implications

\begin{tabular}{|c|c|c|c|c|c|c|c|c|c|}
\hline \multicolumn{6}{|c|}{ A - Total Cost of Purchase of the Furniture from Vendors } & \multicolumn{3}{|c|}{$\begin{array}{l}\text { B - Total Cost of Producing the Furniture } \\
\text { in the institution }\end{array}$} & \multirow{2}{*}{$\begin{array}{c}\text { C - Total } \\
\text { Cost/Amount } \\
\text { Saved } \\
\text { Cost/amount } \\
\text { saved } \\
\text { N }\end{array}$} \\
\hline $\mathrm{S} /$ & $\begin{array}{l}\text { Unit/ } \\
\text { faculty }\end{array}$ & Items & Qty & Unit cost & $\begin{array}{c}\text { Total cost } \\
\mathrm{A}\end{array}$ & Items & $\begin{array}{c}\text { Unit cost } \\
\mathrm{A}\end{array}$ & $\begin{array}{c}\text { Total cost } \\
\quad\end{array}$ & \\
\hline 1 & $\begin{array}{l}\text { Engineering, } \\
\text { Law and } \\
\text { Basic } \\
\text { Medical } \\
\text { Science }\end{array}$ & $\begin{array}{l}\text { Desks } \\
\text { (Table I) }\end{array}$ & 4880 & 40,000 & $195,200,000$. & $\begin{array}{c}\text { Table } \\
7\end{array}$ & $30,000.00$ & $146,400,000$. & $49,2008,000$. \\
\hline 2 & $\begin{array}{l}\text { Engineering, } \\
\text { Law and } \\
\text { Basic } \\
\text { Medical } \\
\text { Science }\end{array}$ & $\begin{array}{c}\text { Executive } \\
\text { Office } \\
\text { Tables } \\
\text { (Table 2) }\end{array}$ & 200 & $145,000$. & $29,000,000$. & $\begin{array}{c}\text { Table } \\
8\end{array}$ & $66,200.00$ & $13,240,000$. & $15,760,000.00$ \\
\hline 3 & Hostel & $\begin{array}{c}\text { Tables } \\
\text { (Tables } \\
3 \text { ) }\end{array}$ & 1950 & $27,620$. & $53,859,000$ & $\begin{array}{c}\text { Table } \\
6\end{array}$ & $26,500.00$ & $5,167,500$. & $48,671,500.00$ \\
\hline 4 & $\begin{array}{l}\text { Faculty of } \\
\text { Engineering } \\
\text { Drawing } \\
\text { Room }\end{array}$ & $\begin{array}{c}\text { Engineeri } \\
\text { ng } \\
\text { Drawing } \\
\text { Tables } \\
\text { (Table 4) }\end{array}$ & 100 & $24,150$. & $2,415,000.00$ & $\begin{array}{c}\text { Table } \\
9\end{array}$ & $38,600.00$ & $3,860,000$. & $-1,445,000.00$ \\
\hline 5 & $\begin{array}{l}\text { Procuremen } \\
\text { t of CNC } \\
\text { MDF Chain } \\
\text { Saw }\end{array}$ & - & - & - & - & & $12,800,000$ & $12,800,000$ & $-12,800,000.00$ \\
\hline 6 & $\begin{array}{l}\text { Automatic } \\
\text { Edge } \\
\text { Banding } \\
\text { Machine }\end{array}$ & - & - & - & - & & $15,000,000$ & $15,000,000$ & $-15,000,000.00$ \\
\hline & Total & & & & $280,474,000$ & & & $196,467,500$ & $84,006,500$. \\
\hline
\end{tabular}

Total Cost $/$ Amount Saved $=$ Total Cost of Purchase of the Furniture from Vendors - Total Cost of Producing the Furniture in the institution $C=A-B=N 280,474,000.00-N 196,467,500.00$ $=$ N84,006,500.00. The Total amount saved if the furniture is produced in the institution is Eighty Four Million, Six Thousand and Five Hundred Naira (N84, 006,500.00) only.

\section{DISCUSSION}

The graph representation as shown in figures 3 and 4 respectively is clear to the extent that the provision of the CNC, MDF Chain Saw and Automatic Edge Banding Machines in addition to the existing Machineries in Engineering Workshop would improve the quantities, of the furniture produced in the institution. It will also put the University in a vantage position for skill acquisition, Internally Revenue Generation (IGR) and entrepreneurship skill development. 


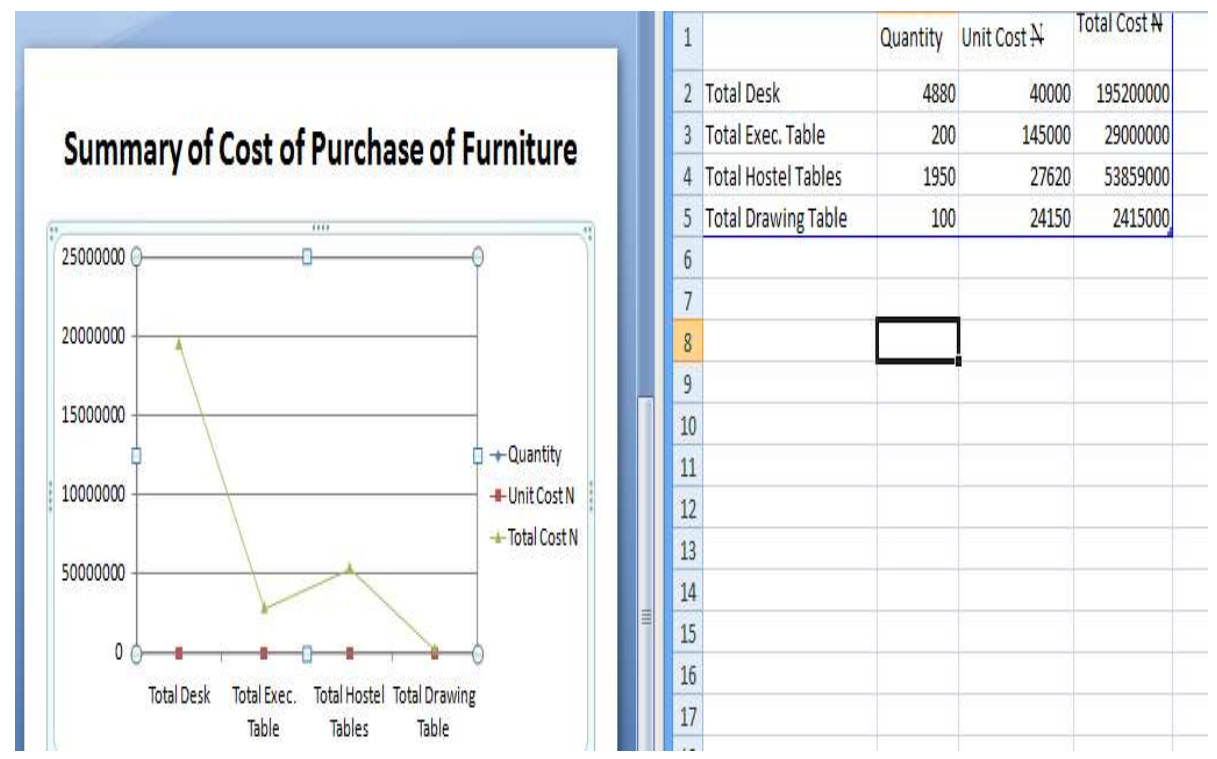

Figure 3 Graphical Presentation of Summary of Cost of Purchase of Furniture

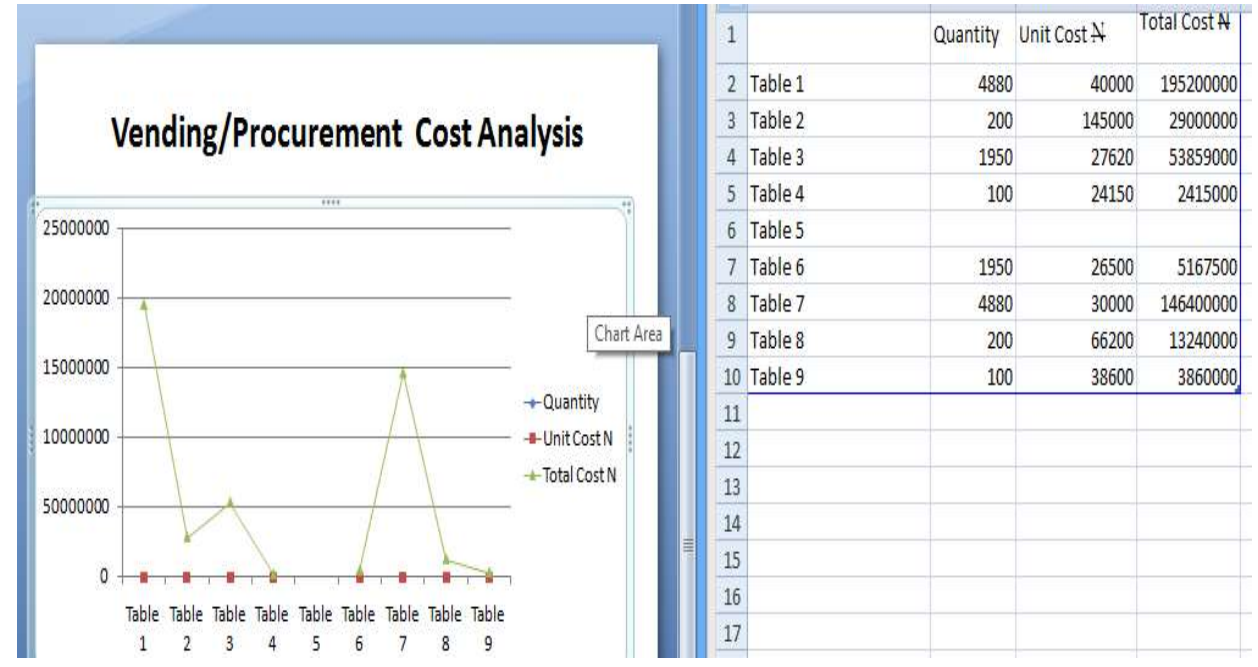

Figure 4 Vending Analysis

\section{CONCLUSION}

The purchase and availability of the CNC MDF Chain Saw and Automatic Edge Banding Machines would ensure the production of quality furniture that can compete and compares favourably with those produced in Europe and America. Availability of the machine in the institution is capable of conserving the foreign exchange expended on the importation of furniture. It will enhance the Skill acquisition and the entrepreneurship development culture in the University. Nigeria being categorized as a tropical Zone has tropical forest ranging from swamp and mangrove swamp forest in the South down to the savannah and grassland in the North. 
Different species of both hard and soft wood are available for making furniture and other wood work product. The availability of the machines, wood, other accessories, with competent and creative staff and the production of the furniture in Engineering Workshop compares favourably to purchasing the furniture in an open market.

\section{REFERENCES}

[1] Abdullahi, S. M. (1998). Innovative Approaches for Funding Technology Education Programs in Nigeria Schools. In A. W. Ajetunmobi, T. A. G. Oladimeji \& K. A. Salami (Eds), Technology Education and the Realization of vision 2010. Annual NATT conferenceMinna. 14th - 17th October.

[2] Grönroos, C., Ojasalo, K. 2004. Service productivity. Towards conceptualization of the transformation of inputs into economic results in services; Journal of Business Research 57, pp. 414-423.

[3] Hartel, I. 2002. Virtual Organization of After-Sales Service in the One-Of-A Kind Industry. In Camarinha-Matos, L. (ed.) Collaborative Business Ecosystems and Virtual Enterprises, IFIP TC5/WG5.5 Third Working Conference on Infrastructures for Virtual Enterprises (PRO-VE'02), May 1-3, 2002, Sesimbra, Portugal.

[4] Heiskala, M. 2005. A Conceptual Model for Modeling Configurable Services from a Customer Perspective. Master's Thesis, Helsinki University of Technology. Espoo, Finland.

[5] Hermann, K. et al. 2003. Computer Aided Service Engineering Tool - Ein Rahmenkonzept für das IT-gestützte Service Engineering. In: H.-J. Bullinger and A.-

[6] W. Scheer (eds.). Service Engineering. Entwicklung und Gestaltung innovativer Dienstleistungen. Berlin, Heidelberg, New York: Springer Verlag, 2003, pp. 647-677.

[7] Heskett, J. L., Sasser, W. E., Schlesinger, L. A. 1997. The Service-Profit Chain, The Free Press, New York, 1997.Abdullahi, S. M. (2003). Evaluation of Vocational Technical Training Programs in Northern Nigeria Prisons. Journal of League of Researchers in Nigeria (JOLORN). 8 (1), 146-153.

[8] Aina, O. (1999). Technical Education in Nigeria - A Bridge to the future, fifth National Biennial Convention of the Auchi Polytechnic. 4th-7th, October.

[9] Aina, O. (2000). Technical and Vocational Education in Nigeria: Vision and action; Blue print and master plan - Federal Ministry of Education (2001 - 2010).

[10] Anyakoha, E. U. (1992). Development and utilization of facilities for home economic education program in Nigerian schools and colleges for manpower development, Nigerian Vocational Journal 2(1), 16 - 24.

[11] Asilokun, B. A. (2004). Development and Managing Schools Workshop towards achieving Sustainable NEEDS. In G. N. Nneji, M. A. Ogunyemi, F. O. N. Onyeukwu, M. Ukponson, S. O. Agbato, E. A. Nnenji (Eds.), Technology Education as an impetus for sustainable NEEDS. 17th Annual NATT conference - Abuja. 94 - 97. 
[12] Atsumbe, B. N. (2002). Mechanisms for Improving Manpower Production in Vocational and Technical Education. Akoka Journal of Education. 1 (2) 165 - 17882

[13] LBNL 2005. Planning and Reporting for Operation \& Maintenance in Federal Energy SavingPerformance Contracts. Lawrence Berkeley National Laboratory, Berkeley, California. Avail http://ateam.lbl.gov/mv/.

[14] LBNL 2007. How to Determine and Verify Operating and Maintenance (O\&M) Savings in Federal Energy Savings Performance Contracts. Lawrence Berkeley National Laboratory, Berkeley, California. Avai: http://ateam.lbl.gov/mv/.

[15] Meador, R.J. 1995. Maintaining the Solution to Operations and Maintenance Efficiency Improvement. World Energy Engineering Congress, Atlanta, Georgia.

[16] NASA. 2000. Reliability Centered Maintenance Guide for Facilities and Collateral Equipment. National Aeronautics and Space Administration, Washington, D.C. February 2000.

[17] Karni, R., Kaner, M. 2007. An engineering tool for the conceptual design of service systems. In: D. Spath and K. Fähnrich (eds.): Advances in Service Innovations.

[18] Kersten, W., Kern, E.-M. and Zink, T. 2003. Collaborative Service Engineering. In: H.-J. Bullinger and A.-W. Scheer (eds.) 2003. Service Engineering. Entwicklung und Gestaltung innovativer Dienstleistungen. Berlin, Heidelberg,

[19] Bester, G. (2004). Further Education and Training in South Africa. In L. Moran \& G. Rumble (Eds). Vocational Education and Training through Open and Distance Learning. Volume 5. London: RoutledgeFalmer.

[20] Boyer, E. (1990). Scholarship Reconsidered: Priorities of the Professoriate, the Carnegie Foundation for the Advancement of Teaching. New Jersey: Princeton University Press. 